\title{
PENGARUH MODEL PEMBELAJARAN DAN MINAT BELAJAR MENGGUNAKAN KOMPUTER TERHADAP HASIL BELAJAR SISWA PADA MATA PELAJARAN MELAKUKAN PROSEDUR ADMINISTRASI
}

\author{
Herlin Munthe , Mukhtar $^{2}$, Efendi Napitupulu ${ }^{3}$ \\ ${ }^{1} S M K$ PAB 12 Saentis, Medan, Sumatera Utara \\ ${ }^{2}$ FMIPA Universitas Negeri Medan, Sumatera Utara \\ ${ }^{3}$ FT Universitas Negeri Medan, Sumatera Utara \\ herlinmunthe@gmail.com
}

\begin{abstract}
Abstrak: Tujuan penelitian ini adalah untuk mengetahui peningkatan hasil belajar siswa pada mata pelajaran produktif kompetensi kejuruan sub kompetensi Melakukan Prosedur Administrasi yang diajar dengan model pembelajaran Quantum Learning dan model Direct Teaching pada Jurusan Pendidikan Administrasi Perkantoran SMK PAB 12 Saentis. Metode penelitian ini adalah metode eksperimen yang melibatkan dua kelompok belajar, yaitu kelompok eksperimen pertama pembelajaran dengan Quantum Learning menggunakan komputer dan kelompok eksperimen kedua pembelajaran dengan Langsung (Direct Teaching) serta siswa yang memiliki minat belajar tinggi dan rendah. Rancangan penelitian disajikan dalam desain faktorial $2 \times 2$ dengan teknik analisis varian (Anava). Hasil penelitian diperoleh hasil bahwa pembelajaran dengan menggunakan model pembelajaran Quantum Learning memberi pengaruh yang lebih baik terhadap hasil belajar dibandingkan dengan model pembelajaran Direct Teaching. Tinggi rendah tingkat minat belajar memberi pengaruh yang berbeda secara signifikan terhadap hasil belajar dan tidak ada interaksi antara pembelajaran dengan menggunakan model pembelajaran dengan minat belajar siswa terhadap hasil belajar.
\end{abstract}

Kata Kunci: model pembelajaran, quantum learning, direct teaching, minat belajar

\begin{abstract}
The purpose of this study was to determine the improvement of student learning outcomes on productive subjects in sub-competence vocational competencies Conducting Administrative Procedures which were taught using Quantum Learning learning models and Direct Teaching models in Education Department Office Administration SMK PAB 12 Saentis. This research method is an experimental method that involves two study groups, namely the first experimental group learning with Quantum Learning using a computer and the experimental group both Direct Teaching and students who have high and low learning interests. The research design is presented in a $2 \times 2$ factorial design with variance analysis technique (Anava). The results showed that learning using the Quantum Learning learning model had a better influence on learning outcomes compared to the Direct Teaching learning model. High low level of interest in learning gives a significantly different influence on learning outcomes and there is no interaction between learning using learning models with student learning interest in learning outcomes.
\end{abstract}

Keywords: learning model, quantum learning, direct teaching, interest in learning

\section{PENDAHULUAN}

Pada model pembelajaran apapun sebaiknya menggunakan alat yang sesuai pada proses pembelajaran untuk memudahkan penyampaian maksud dan tujuan yang hendak dicapai. Model pembelajaran banyak cenderung ditentukan oleh guru. Setiap model yang cocok untuk satu mata pelajaran, belum tentu untuk mata pelajaran lain. Bahkan dalam satu mata pelajaran, untuk menyampaikan topik atau konsep tertentu sering memerlukan model yang berbeda. Sedangkan alat merupakan suatu sarana atau alat yang digunakan untuk membantu menyampaikan materi pembelajaran kepada peserta didik.

Sistem ini mengoptimalkan modalitas belajar siswa yang diibaratkan seperti mengubah energi menjadi cahaya seperti halnya Teori Quantum (De Porter dan Hernacki, 2007: 
16). Modalitas tersebut berupa Visual, Auditorial, Kinestetik (V- A-K). Modalitas Visual mengakses citra visual yang diciptakan maupun diingat. Auditorial mengakses segala jenis bunyi dan kata diciptakan maupun diingat. Kinestetik mengakses segala jenis gerak dan emosi diciptakan maupun diingat.

Dalam pembelajaran Quantum Learning, hubungan guru dan peserta didik dideskripsikan menjadi prinsip "bawalah dunia mereka ke dunia, antarkan dunia ke dunia mereka". Quantum Learning akan berlangsung dengan syarat menggunakan rancangan pembelajaran dan guru yang tepat. Rancangan pembelajaran Quantum Learning diawali dengan tumbuhkan, yaitu menumbuhkan suasana yang sangat menyenangkan dan menggembirakan dihati setiap peserta didik, dalam suasana rileks, menumbuhkan interaksi dengan peserta didik, kemudian masuk ke alam pikiran mereka dan membawa alam pikiran peserta didik ke alam pikiran pendidik. Alami, yaitu menciptakan dan mendatangkan pengalaman umum yang dapat dimengerti semua peserta didik, menghindari penggunaan istilah yang sulit dimengerti peserta didik dan mendorong hasrat alami otak untuk menjelajah informasi yang ada.

Pembelajaran dengan model Quantum Learning mengutamakan proses pembelajaran yang nyaman dan menyenangkan. Model pembelajaran Quantum Learning ini belum banyak digunakan oleh para guru. Mata pelajaran produktif kompetensi kejuruan sub kompetensi Melakukan Prosedur Administrasi dapat dilaksanakan pada situasi yang santai, nyaman dan menyenangkan serta dapat diiringi dengan alunan musik.

Minat merupakan suatu keadaan dimana seseorang mempunyai perhatian terhadap sesuatu disertai keinginan untuk mengetahui dan mempelajari, membuktikan bahkan memilikinya. Minat timbul karena adanya perhatian yang mendalam terhadap sesuatu objek, perhatian tersebut menimbulkan keinginan untuk mengetahui, mempelajari, membuktikannya bahkan sampai memilikinya. Hal ini menunjukkan bahwa dalam minat, disamping perhatian juga terkandung suatu usaha untuk mendapatkan sesuatu dari objek minat tersebut.

Menurut Slameto (2010: 57), minat sangat besar pengaruhnya terhadap belajar, karena bila bahan pelajaran yang dipelajari tidak sesuai dengan minat siswa maka siswa tidak akan belajar dengan sebaik-baiknya, karena tidak ada daya tarik tersendiri baginya. Sehingga siswa enggan untuk belajar, salah satunya dikarenakan siswa tidak memperoleh kepuasan dari pelajaran itu kemudian menjadi bosan terhadap pelajaran tersebut. Bahan pelajaran yang menarik minat siswa, lebih mudah dipelajari dan disimpan karena minat mampu menambah kegiatan belajar yang aktif.

\section{Hakikat Hasil Belajar Melakukan Prosedur Administrasi}

Belajar merupakan proses aktif yang pada satu tujuan, yaitu adanya perubahan diri seseorang, seperti dari yang tidak tahu menjadi tahu dari yang tidak mengerti menjadi mengerti. Kegiatan belajar dapat berlangsung melalui pengamatan, pendengaran, membaca dan meniru. Dalam keseluruhan proses pendidikan di sekolah belajar merupakan yang paling pokok. Belajar merupakan suatu proses perubahan tingkah laku sebagai hasil dari interaksi dengan lingkungannya dalam memenuhi kebutuhan hidupnya.

Dimyati dan Mudjiono (2009:10), menyatakan bahwa proses pendidikan yang terjadi di sekolah adalah kegitan belajar dan mengajar dimana kegiatan belajar dilakukan oleh siswa (peserta didik) sedangkan kegiatan mengajar dilakukan oleh guru. Peserta didik setelah mengalami proses pendidikan di sekolah diharapkan menjadi manusia yang bertanggung jawab terhadap diri sendiri dan lingkungannya, berkepribadian yang baik dan bermoral. Proses pembelajaran dinilai berhasil bila siswa dapat belajar sesuai dengan tujuan yang dirancang. Kegiatan pembelajaran juga harus mempertimbangkan dengan perkembangan anak. Implikasi prinsip perkembangan adalah individu yang pada dirinya belajar secara bertahap, apa yang dipelajari sebelumnya menjadi dasar bagi proses belajar selanjutnya, dan hasil belajar lebih lanjut cenderung lebih kompleks dari hasil belajar sebelumnya.

Selanjutnya Smaldino, dalam Driscoll (2000: 11), mengatakan belajar (learning) perubahan terus menerus dalam kemampuan yang berasal dari pengalaman pemelajar dan interaksi pemelajar dengan dunia. Belajar merupakan pengembangan pengetahuan, keterampilan atau sikap yang baru ketika seseorang berinteraksi dengan informasi dan lingkungan ( Smaldino 2011: 11)

Setiap pekerjaan akan mendatangkan hasil, demikian juga dengan belajar, tentu ada hasilnya yang disebut dengan hasil belajar. 
Menurut Annurahman (2003) bahwa: "Hasil belajar adalah kemampuan yang diperoleh anak setelah melalui kegiatan belajar yang terprogram dan terkontrol yang disebut kegiatan pembelajaran dan tujuan belajar yang ditetapkan terlebih dahulu oleh guru". Proses belajar mencapai puncaknya pada hasil belajar. Anak yang berhasil dalam belajar adalah yang berhasil mencapai tujuan-tujuan pembelajaran.

Sedangkan menurut Sudjana (2005):"hasil belajar adalah kemampuankemampuan yang dimiliki siswa setelah ia menerima pengalaman belajarnya". Hasil belajar merupakan suatu gambaran sebagai hasil usaha yang dilakukan anak didik dalam proses belajar dengan berbagai macam tingkat keberhasilan yang berbeda. Hasil belajar dikelas dapat diterapkan ke dalam situasi - situasi diluar sekolah. Dengan kata lain, siswa dapat dikatakan berhasil dalam belajar apabila dapat menstransfer hasil belajarnya ke dalam situasi yang sesungguhnya didalam kehidupan masyarakat sehari-hari.

Hasil belajar merupakan tujuan akhir dilaksanakannya kegiatan pembelajaran di sekolah. Hasil belajar dapat ditingkatkan melalui usaha sadar yang dilakukan secara sistematis mengarah kepada perubahan yang positif yang kemudian disebut dengan proses belajar. Akhir dari proses belajar adalah perolehan suatu hasil belajar siswa. Hasil belajar siswa di kelas terkumpul dalam himpunan hasil belajar kelas. Semua hasil belajar tersebut merupakan hasil dari suatu interaksi tindak belajar dan tindak mengajar. Dari sisi guru, tindak mengajar di akhiri dengan proses evaluasi hasil belajar, sedangkan dari sisi siswa, hasil belajar merupakan berakhirnya penggal dan puncak proses belajar (Dimyati dan Mudjiono, 2009: 3).

Selanjutnya Warsito (dalam Depdiknas, 2006: 125) mengemukakan bahwa hasil dari kegiatan belajar ditandai dengan adanya perubahan perilaku ke arah positif yang relatif permanen pada diri orang yang belajar. Sehubungan dengan pendapat itu, maka Wahidmurni, dkk. (2010: 18) menjelaskan bahwa sesorang dapat dikatakan telah berhasil dalam belajar jika ia mampu menunjukkan adanya perubahan dalam dirinya. Perubahanperubahan tersebut di antaranya dari segi kemampuan berpikirnya, keterampilannya, atau sikapnya terhadap suatu objek.

Jika dikaji lebih mendalam, maka hasil belajar dapat tertuang dalam taksonomi Bloom, yakni dikelompokkan dalam tiga ranah (domain) yaitu domain kognitif atau kemampuan berpikir, domain afektif atau sikap, dan domain psikomotor atau keterampilan. Sehubungan dengan itu, Gagne (dalam Sudjana, 2010: 22) mengembangkan kemampuan hasil belajar menjadi lima macam antara lain: (1) hasil belajar intelektual merupakan hasil belajar terpenting dari sistem lingsikolastik; (2) strategi kognitif yaitu mengatur cara belajar dan berfikir seseorang dalam arti seluas-luasnya termasuk kemampuan memecahkan masalah; (3) sikap dan nilai, berhubungan dengan arah intensitas emosional dimiliki seseorang sebagaimana disimpulkan dari kecenderungan bertingkah laku terhadap orang dan kejadian; (4) informasi verbal, pengetahuan dalam arti informasi dan fakta; dan (5) keterampilan motorik yaitu kecakapan yang berfungsi untuk lingkungan hidup serta memprestasikan konsep dan lambang.

Untuk mengetahui hasil belajar seseorang dapat dilakukan dengan melakukan tes dan pengukuran. Tes dan pengukuran memerlukan alat sebagai pengumpul data yang disebut dengan instrumen penilaian hasil belajar. Menurut Wahidmurni, dkk. (2010: 28), instrumen dibagi menjadi dua bagian besar, yakni tes dan non tes. Selanjutnya, menurut Hamalik (2006: 155), memberikan gambaran bahwa hasil belajar yang diperoleh dapat diukur melalui kemajuan yang diperoleh siswa setelah belajar dengan sungguhsungguh. Hasil belajar tampak terjadinya perubahan tingkah laku pada diri siswa yang dapat diamati dan diukur melalui perubahan sikap dan keterampilan. Perubahan tersebut dapat diartikan terjadinya peningkatan dan pengembangan yang lebih baik dibandingkan dengan sebelumnya.

Melakukan Prosedur Administrasi merupakan salah satu pembelajaran produktif pada program keahlian administrasi perkantoran. Melakukan Prosedur Administrasi merupakan suatu ilmu yang mempelajari mengenai cara menulis berbagai surat baik surat bisnis maupun surat dinas. Tujuan akhir setelah mempelajari Kompetensi "Melakukan Prosedur Administrasi" siswa harus mempunyai pengetahuan dan keterampilan dalam membuat/mengetik surat dan menyimpannya dengan baik dan benar.

Pokok bahasan mengenai surat menyurat adalah salah satu pokok bahasan di dalam kompetensi Melakukan Prosedur Administrasi. Pokok bahasan melakukan surat menyurat menyangkut berbagai jenis surat diantaranya adalah surat bisnis, surat permintaan penawaran dan surat penawaran. 
"Mengetik adalah pekerjaan yang mendasar terdapat pada semua bidang, baik itu dalam organisasi swasta, organisasi pemerintah ataupun organisasi kepartaian maupun organisasi yang lain" (Marimin dkk., 2012:1). Untuk itu siswa Sekolah Menengah Kejuruan yang merupakan satuan pendidikan yang menyiapkan tenaga kerja yang berkompeten dibidangnya, diharapkan mampu menguasai keterampilan mengetik dengan cepat dan tepat.

Kecepatan mengetik merupakan salah satu keterampilan yang harus dikuasai oleh siswa dalam kompetensi menggunakan peralatan kantor. Hal ini sesuai dengan tujuan pendidikan kejuruan yang mencetak lulusan yang siap kerja dengan menjadi tenaga kerja yang profesional, sehingga siswa diharapkan mampu bekerja dengan cepat dalam hal pekerjaan ketik mengetik. Menurut Marimin (2012:1) menyatakan:

\section{Hakikat Model Pembelajaran}

Menurut Yamin (2008: 161), model pembelajaran adalah suatu proses kegiatan komunikasi yang dilakukan secara timbal balik antara siswa, mahasiswa dengan guru, dosen dalam memahami, mendiskusi,Tanya jawab, mendemonstrasi, mempraktekkan materi pelajaran di dalam kelas. Dari pendapat diatas dapat disimpulkan bahwa pembelajaran adalah suatu cara yang dipakai guna membahas bahan pelajaran untuk mencapai tujuan pengajaran.

Pembelajaran merupakan suatu kegiatan yang melibatkan seseorang dalam upaya memperoleh pengetahuan, keterampilan dan nilai nilai positif dengan memanfaatkan berbagai sumber untuk belajar. Susiliana dan Riyana (2007: 1). Pembelajaran dapat melibatkan dua pihak yaitu siswa sebagai pebelajar dan guru sebagai fasilitator. Yang terpenting dalam kegiatan pembelajaran adalah terjadinya proses belajar (learning process).

Dalam uraiaan selanjutnya, istilah "model" digunakan untuk menunjukkan pengertian yang pertama sebagai kerangka konseptual. Atas dasar pemikiran tersebut, yang disebut dengan "Model Pembelajaran" adalah kerangka konseptual yang melukiskan prosedur yang sistematis dalam mengorganisasikan pengalaman belajar untuk mencapai tujuan belajar tertentu. Model pembelajaran berfungsi sebagai pedoman bagi para perancang pembelajaran dan para pengajar dalam merencanakan serta melaksanakan aktifitas pembelajaran (Udin: 2001). Dengan demikian, aktivitas pembelajaran merupakan kegiatan yang tertata secara sistematis.

Sebagaimana ditegaskan oleh Joyce dan Weil (1986) bahwa hakikat mengajar atau Teaching dalam membantu siswa memperoleh ide, keterampilan, nilai, cara perfikir, sarana untuk mengekspresikan dirinya, dan cara-cara belajar bagaimana belajar. Dalam kenyataanya, hasil akhir atau hasil jangka panjang dari proses pembelajaran adalah -"the student's increased capabilities to learn more easly and effectively in the future", yaitu siswa mengingkatkan kemampuannya untuk dapat belajar lebih mudah dan lebih efektif dimasa yang akan datang (Joyce dan Weil, 1986:1). Oleh karena itu proses pembelajaran tidak hanya memiliki makna deskriptif dan keterkinian, akan tetapi juga bermakna prospektif dan berorientasi masa depan.

\section{Model Pembelajaran Quantum Learning}

Menurut De Porter dkk (2004: 3), Model pembelajaran Quantum Learning adalah suatu pengetahuan dan metodologi belajar yang menciptakan lingkungan belajar yang efektif, merancang kurikulum, menyampaikan isi dan strategi belajar untuk memudahkan proses belajar mengajar yang berhasil dan efektif Model ini telah digunakan dan dikembangkan dalam Quantum Learning dimaksudkan untuk membantu meningkatkan keberhasilan pembelajaran.

Untuk memudahkan mengingat dan untuk keperluan operasional pembelajaran Quantum Learning dikenal dengan konsep TANDUR yang merupakan akronim dari : Tumbuhkan, Alami, Namai, Demostrasikan, Ulangi dan Rayakan. Unsur-unsur ini membentuk basis struktur yang melandasi pendekatan pembelajaran Quantum Learning.

Kerangka TANDUR dapat membawa siswa menjadi tertarik dan berminat pada setiap pelajaran apapun mata pelajaran, tingkat kelas, dengan beragam budayanya, jika pada para guru betul-betul menggunakan prinsipprinsip atau nilai-nilai pembelajaran Quantum Learning. Kerangka ini juga memastikan bahwa mereka mengalami pembelajaran, berlatih, dan menjadikan isi pelajaran nyata bagi mereka sendiri dan akhirnya mencapai kesuksesan dalam belajar. Model pembelajaran Quantum learning De Porter (2007: 10 ) dikenal dengan singkatan TANDUR yaitu : Tumbuhkan, Alami, Namai, Demonstrasikan, Ulangi dan Rayakan. 


\section{Hakikat Model Pembelajaran Langsung (Direct Teaching)}

Pengetahuan yang bersifat informal dan prosedural yang menjurus pada keterampilan dasar akan lebih efektif jika disampaikan dengan cara pembelajaran langsung (Direct Teaching).

Menurut Sanjaya (2006: 47) ciri pembelajaran langsung (direct teaching) adalah pembelajaran yang menekankan kepada proses penyampain secara verbal dari seorang guru kepada sekelompok siswa dengan maksud agar siswa dapat menguasai materi pelajaran secara optimal. Pusat pelajaran adalah guru, siswa mendengar dan mencatat seperlunya, komunikasi terjadi satu arah, dan menyama ratakan kemampuan akademik siswa. Model pembelajaran langsung (direct teaching) adalah model pembelajaran yang mendudukan posisi guru sebagai pengatur utama kegiatan belajar mengajar siswa. Pada umumnya metode yang digunakan dalam model pembelajaran ini berlangsung satu arah, pengajar memberikan ide arau informasi dan siswa menerimanya.

Model pembelajaran langsung (direct teaching) memerlukan perencanaan pelaksaan yang sangat hati-hati dari pihak guru. Agar berjalan efektif, system pengelolaan pembelajaran yang dilakukan oleh guru harus menjamin terjadinya keterlibatan siswa dalam memperhatikan, mendengar, dan resitasi (tanya jawab) yang terencana (Departemen Pendidikan Nasional, 2005). Hakikat mengajar menurut pandangan langsung (direct teaching) adalah menyampaikan ilmu pengetahuan kepada siswa yang ditempatkan sebagi objek yang menerima apa yang diberikan guru. Jika memberikan pertanyaan, biasanya guru menuntun siswa untuk menentukan jawaban dengan pertanyaan penuntun, selain itu guru akan memberi informasi atau jawaban langsung kepada siswa dengn tujuan untuk menegaskan atau mengingat kembali suatu fakta atau prosedur.

Menurut Sanjaya (2006: 66) dalam menggunakan model pembelajaran langsung (direct teaching), guru harus memahami dan mengusai tiga strategi agar pembelajaran dapat berjalan efektif, yaitu : (1) merumuskan tujuan yang ingin di capai, (2) menguasai materi pelajaran dengan baik, dan (3) mengenali situasi, kondisi dan berbagai hal yang dapat mempengaruhi proses penyampaian meteri pelajaran. Kadangkala materi pelajaran yang di sampaikan dengan model langsung (direct teaching) sulit dipahami oleh siswa, hal ini disebabkan tidak diawalinya pembelajaran dengan memberikan gambaran umum pelajaran secara keseluruhan, sehingga sulit dicari keterkaitan dari setip pokok bahasan yang dipelajari. Selain itu dengan model langsung (direct teaching) umumnya sering menimbulkan kejenuhan pada siswa, karena guru menyampaikan meteri dengan metode ceramah secara monoton, diikuti dengan kegiatan memberikan contoh, mengadakan latihan dan memberikan tugas. Kegiatan ini dilakukan secara berulang-ulang dalam tiap-tiap pertemuan.

\section{Hakikat Media Dalam Pembelajaran}

Menutut Susilana dan Riyana (2007:

1) pembelajaran merupakan suatu kegiatan yang melibatkan seseorang dalam upaya memperoleh pengetahuan, keterampilan dan nilai nilai positif dengan memanfaatkan berbagai seumber untuk belajar. Pembelajaran dapat melibatkan dua pihak yaitu siswa sebagai pembelajar dan guru sebagai fasilitator. Yang terpenting dalam kegiatan pembelajaran adalah terjadinya proses belajar ( learning proses ). Sesuatu dikatakan hasil belajar kalau memenuhi beberapa ciri berikut : (1) belajar sifatnya disadari, dalam hal ini siswa merasa bahwa dirinya sedang belajar, timbul dalam dirinya motivasi untuk memiliki pengetahuan yang diharapkan sehingga tahapan tahapan dalam belajar sampai pengetahuan itu dimiliki secara permanen (retensi) betul betul disadari sepenuhnya. (2) hasil belajar diperoleh dengan adanya proses, dalam hal ini pengetahuan diperoleh tidak secara spontanitas, instant, namun bertahap (sequensial). Seorang anak bisa membaca tentu tidak diperoleh hanya dalam waktu sesaat nemun berproses cukup lama, kemudian membaca diawali dengan kemampuan mengeja, mengenal huruf, kata dan kalimat.

Kata "media" berasal dari kata Latin, merupakan bentuk jamak dari kata "medium". Secara harfiah kata tersebut mempunya arti perantara atau pengantar. Menurut Heinich dalam Susila dan Riyana (2007: 6) media merupakan alat saluran komunikasi. Media berasal dari bahasa latin dan merupakan bentuk jamak dari "medium" yang secara harfiah berarti "perantara" yaitu perantara sumber pesan ( $a$ source) dengan penerima pesan (a receiver). Heinich mencontohkan media ini seperti film, 
televisi, diagram, bahan cetak, (printed materials), komputer dan instruktur.

$$
\text { Smaldino (2012: 274) Media }
$$

merupakan sebuah kombinasi dari material pengajaran, seperti: ruang kelas, modul, komputer, media cetak, papan kapur dan papan putih. Selain pengertian media yang telah diuraikan diatas, masih terdapat pengertian lain yang dikemukakan oleh beberapa ahli berikut ini : (1) teknologi pembawa pesan yang dapat dimanfaatkan untuk keperluan pembelajaran Menurut Schramm, Dalam Susilana dan Riyana (2007: 6), (2) sarana fisik untuk menyampaikan materi pembelajaran seperti buku, film, video, slide, dan sebagainya. Menurut Briggs dalam Susilana dan Riyana (2007: 6), (3) sarana komunikasi dalam bentuk cetak maupun pandang dengar, termasuk teknologi perangkat kerasnya NEA dalam Sisilana dan Riyana (2007: 6).

Sudjana dan Rivai dalam Arsyad (2009: 24-25), manfaat media pengajaran adalah : 1) pengajaran akan lebih menarik perhatian siswa sehingga dapat menumbuhkan motivasi belajar; 2) bahan pengajaran akan lebih jelas maknanya sehingga dapat lebih dipahami oleh siswa dan memungkinkanya menguasi dan mencapai tujuan pengajaran; 3) metode mengajar akan lebih bervariasi, tidak sematamata komunikasi verbal melalui penuturan kata-kata oleh guru, sehingga siswa tidak bosan dan guru tidak kehabisan tenaga, apalagi kalau guru mengajar pada setiap jam pelajaran; 4) siswa dapat lebih banyak melakukan kegiatan belajar sebab tidak hanya mendengarkan uraian guru, tetapi juga aktivitas lain seperti mengamati, melakukan, mendemonstrasikan, memerankan, dan lain- lain.

Manfaat media pendidikan menurut Hamalik dalam Arsyad (2009:25), yaitu: (1) meletakkan dasar-dasar yang konkret untuk berfikir, mengurangi verbalisme (2) memperbesar perhatian siswa. (3) meletakkan dasar-dasar penting untuk perkembangan belajar, oleh karena itu membuat pelajaran lebih mantap. (4) memberikan pengalaman nyata yang dapat menumbuhkan kegiatan berusaha sendiri di kalangan siswa. (5) menumbuhkan pemikiran yang teratur dan kontinyu terutama melalui gambar hidup. (6) membantu tumbuhnya pengertian yang dapat membantu perkembangan kemampuan berbahasa. (7) memberikan pengalaman yang tidak mudah diperoleh dengan cara lain, dan membantu efisiensi dan keragaman yang lebih banyak dalam belajar.

Menurut Leshin dalam Arsyad (2009: 81101), media dibedakan menjadi beberapa kelompok: (1) media berbasis manusia, merupakan media yang digunakan untuk mengirimkan dan mengkomunikasikan pesan atau informasi, meliputi dosen, guru, instruktur, tutor dan sejenisnya. (2) media berbasis cetak, merupakan bahan yang disiapkan di atas kertas meliputi buku teks, modul, jurnal, majalah, artikel, dan sejenisnya. (3) media berbasis visual, meliputi buku, gambar, foto, sketsa, diagram, bagan/chart, grafik, peta, poster, kartun, transparansi, slide dan sejenisnya. (4) media berbasis audio-visual, meliputi video, film, program slide-tape, televisi, dan sejenisnya. (5) media berbasis komputer, merupakan mesin yang memiliki kemampuan untuk menggabungkan dan mengendalikan berbagai alat elektronik seperti CD player, video tape dan audio.

Menurut Arsyad (2002: 75-76), beberapa kriteria yang perlu diperhatikan dalam memilih media: (1) sesuai dengan tujuan yang ingin dicapai, pemilihan media mengacu kepada salah satu atau gabungan dari dua atau tiga ranah kognitif, afektif dan psikomotorik. (2) tepat untuk mendukung isi pelajaran yang sifatnya fakta, konsep, prinsip, generalisasi. (3) praktis, luwes, dan bertahan, media yang dipilih mudah diperoleh, atau mudah dibuat sendiri oleh guru dan sebaiknya dapat digunakan di manapun dan kapanpun, serta mudah dipindahkan dan dibawa kemana-mana. (4) guru terampil menggunakannya. (5) pengelompokan sasaran yang tepat, untuk kelompok besar atau kelompok kecil. 6) mutu teknis, media harus memenuhi persyaratan teknis tertentu.

Rumusan masalah dalam penelitian ini adalah: (1) Apakah hasil belajar siswa pada mata pelajaran produktif kompetensi kejuruan sub kompetensi Melakukan Prosedur Administrasi yang diajar dengan model pembelajaran Quantum Learning lebih tinggi dari model Direct teaching pada Jurusan Pendidikan Administrasi Perkantoran?; (2) Apakah hasil belajar siswa pada mata pelajaran produktif kompetensi kejuruan sub kompetensi Melakukan Prosedur Administrasi yang memiliki minat belajar tinggi lebih tinggi dari yang memiliki minat belajar rendah pada Jurusan Pendidikan Administrasi Perkantoran?; dan (3) Apakah ada pengaruh interaksi model pembelajaran dan minat belajar terhadap hasil belajar siswa pada 
mata pelajaran produktif kompetensi kejuruan sub kompetensi "Melakukan Prosedur Administrasi" siswa Jurusan Pendidikan Administrasi Perkantoran?

\section{METODE}

Penelitian dilaksanakan di SMK PAB 12 Saentis Kabupaten Deli Serdang Objek Penelitian adalah siswa kelas X. Populasi adalah totalitas semua nilai yang mungkin, hasil menghitung ataupun pengukuran kuantitatif maupun kualitatif mengenai karakteristik tertentu dari semua anggota kumpulan yang lengkap dan jelas yang ingin dipelajari sifat sifatnya Sudjana (2009: 6). Populasi penelitian ini adalah seluruh siswa kelas $X$ yang terdiri dari 4 kelas, yaitu kelas X- BM 1, X- BM 2, XBM 3 dan X-BM 4. Dalam penelitian ini peneliti mengambil keempat kelas menjadi sampel (total sampling). Dari empat kelas tersebut kemudian ditentukan secara acak 1 kelas diberikan Model Pembelajaran Quantum Learning (kelas X-BM2) dan 1 kelas (kelas XBM3) diberikan Model Pembelajaran Langsung (Direct Teaching).

Metode penelitian yang digunakan adalah metode penelitian eksperimen yang melibatkan dua kelompok belajar, yaitu kelompok eksperimen pertama pembelajaran dengan Quantum Learning menggunakan komputer dan kelompok eksperimen kedua pembelajaran dengan Langsung (Direct Teaching) menggunakan Komputer. Minat belajar dibedakan menjadi minat belajar tinggi dan rendah. Rancangan penelitian disajikan dalam desain faktorial 2 x 2 dengan teknik analisis varian (ANAVA), pada table 1 .

Tabel 1. Desain Penelitian

\begin{tabular}{ccc}
\hline Model Pembelajaran & Quantum learning & $\begin{array}{c}\text { Langsung (Direct } \\
\text { Teaching) }\end{array}$ \\
Minat Belajar & $\left(\mathrm{A}_{1} \mathrm{~B}_{1}\right)$ & $\left(\mathrm{A}_{2} \mathrm{~B}_{1}\right)$ \\
$\left(\mathrm{B}_{1}\right)$ & $\left(\mathrm{A}_{1} \mathrm{~B}_{2}\right)$ & $\left(\mathrm{A}_{2} \mathrm{~B}_{2}\right)$ \\
\hline
\end{tabular}

Keterangan :

$\mathrm{A} \quad=$ Model pembelajaran

$\mathrm{B}=$ Minat belajar menggunakan komputer

$\mathrm{A}_{1} \mathrm{~B}_{1}=$ Hasil belajar siswa dengan yang diajarkan dengan menggunakan Model pembelajaran quantum learning dengan minat belajar tinggi.

$\mathrm{A}_{1} \mathrm{~B}_{2}=$ Hasil belajar siswa dengan yang diajarkan dengan menggunakan Model pembelajaran quantum learning dengan minat belajar rendah.

$\mathrm{A}_{2} \mathrm{~B}_{1}=$ Hasil belajar siswa dengan yang diajarkan dengan menggunakan Model pembelajaran Langsung (Direct Teaching) dengan minat belajar tinggi.

$\mathrm{A}_{2} \mathrm{~B}_{2}=$ Hasil belajar siswa dengan yang diajarkan dengan menggunakan Model pembelajaran Langsung (Direct Teaching) dengan minat belajar rendah.
Uji Instrumen Angket Minat Belajar

Uji Validitas Butir Angket

Validitas adalah pengujian untuk mengetahui tingkat kesahihan butir angket sehingga mampu mangukur kemampuan anak. Validasi yang digunakan adalah validasi butir yaitu dengan melihat validitas tiap item angket. Angka validitas suatu instrumen dapat dihitung dengan rumus Korelasi Pearson Product Moment .

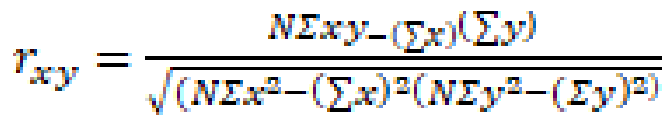

Keterangan:

$r_{x y}=$ Koefisien korelasi antara variabel

$\mathrm{X}$ dan variabel $\mathrm{Y}$

$\Sigma x_{y}=$ Jumlah perkalian antara variabel $\mathrm{x}$ dan $\mathrm{Y}$

$\sum x^{2}=$ Jumlah dari kuadrat nilai $\mathrm{X}$

$\Sigma y^{2}=$ Jumlah dari kuadrat nilai Y

$\left(\sum x\right)^{2}=$ Jumlah nilai $\mathrm{X}$ kemudian dikuadratkan

$(\Sigma y)^{2}=$ Jumlah nilai Y kemudian dikuadratkan 
Validitas didefinisikan sebagai ukuran seberapa cermat suatu tes melakukan fungsi ukurnya. Tes hanya dapat melakukan fungsinya dengan cermat kalau ada "sesuatu" yang diukur.

Hasil uji validitas butir angket, dari 25 butir angket yang dibuat, ternyata ada 6 butir yang tidak valid yaitu soal angket nomor $5,12,15,21,24$ dan 25 , jadi jumlah soal angket yang dipakai adalah 19 butir.

Uji Reliabilitas Angket

Reliabilitas menunjukkan bahwa instrumen yang digunakan dapat dipercaya sebagai alat pengumpul data yang bersangkutan. Suatu tes dapat mempunyai taraf kepercayaan yang tinggi jika tes tersebut dapat memberikan hasil yang tetap, artinya tidak berubah-ubah. Untuk menghitung koefisien realibilitas tes bentuk obyektif digunakan rumus rumus Alpha Cronbach (KR-21), karena instrumen penelitian ini berbentuk angket dan skala bertingkat, berikut :

$r_{11}=\left(\frac{n}{n-1}\right)\left(1-\frac{\sum \sigma_{t}^{2}}{\sigma_{t}^{2}}\right)$

Keterangan :

$$
\begin{array}{ll}
\mathrm{r}_{11} & =\text { nilai reliabilitas yang dicari } \\
\mathrm{n} & =\text { jumlah butir angket } \\
\sum \sigma_{\mathrm{t}}^{2} & =\text { jumlah varians skor butir } \\
& \text { angket } \\
\sigma_{\mathrm{t}}^{2} & =\text { varians total }
\end{array}
$$

Hasil uji reliabel (keterandalan) instrumen hasil belajar diperoleh nilai r11 $=0,903$ (Tinggi).

\section{Teknik Analisis Data}

Uji Persyaratan Analisis

Untuk menguji hipotesis penelitian digunakan teknik analisis data dengan analisis varian (ANAVA) Dua jalur dengan taraf signifikan 0,05 . Untuk menggunakan ANAVA Dua jalur perlu dipenuhi beberapa persyaratan, yaitu : 1) data yang digunakan harus berdistribusi normal, maka dilakukan uji normalitas dengan menggunakan uji Lieliefors, dan 2) data harus memiliki varians populasi yang homogen maka harus dilakukan uji homogenitas varians dengan menggunakan uji $\mathrm{F}$ dan uji Bartlett.

Kriteria pengujian untuk uji normalitas adalah : Jika $\mathrm{L}_{0}<\mathrm{L}_{\text {tabel, }}$, maka sampel berdistribusi normal; Jika $\mathrm{L}_{0} \geq \mathrm{L}_{\text {tabel}}$, maka sampel tidak berdistribusi normal. Kriteria pengujian untuk uji homogenitas adalah : Jika $F_{\text {hitung }}<\mathrm{F}_{\text {tabel}}$, maka sampel memiliki varians yang homogen; Jika Jika $\mathrm{F}_{\text {hitung }} \geq \mathrm{F}_{\text {tabel }}$, maka sampel tidak memiliki varians yang homogen.

Pengujian Hipotesis

Untuk keperluan hipotesis maka perlu dirumuskan hipotesis statistik :

Hipotesis 1

$$
\begin{aligned}
& \text { Ho : } \mu A_{1} \leq \mu A_{2} \\
& \text { Ha } ; \mu A_{1}>\mu A_{2}
\end{aligned}
$$

Hipotesis 2 :

$$
\begin{aligned}
\text { Ho }: \mu B_{1} \leq \mu B_{2} \\
\text { Ha }: \mu B_{1}>\mu B_{2}
\end{aligned}
$$

Hipotesis 3 :

Ho : interaksi $\mathrm{AXB}=0$

$$
\mathrm{Ha}: \text { interaksi } \mathrm{AXB} \neq 0
$$

Keterangan :

$\mu A_{1}$ Nilai rata-rata hasil belajar siswa kelompok Quantum Learning

$\mu A_{2}$ Nilai rata-rata hasil belajar siswa kelompok Direct Teaching

$\mu B_{1}$ Nilai rata-rata hasil belajar siswa dengan minat belajar tinggi

$\mu B_{2}$ Nilai rata-rata hasil belajar siswa dengan minat belajar rendah

$\mathrm{AXB}=0$, tidak terdapat interaksi model pembelajaran dan minat belajar

AXB $\neq 0$, terdapat interaksi model pembelajaran dan minat belajar

\section{HASIL PENELITIAN}

Pengujian Hipotesis penelitian pertama, kedua dan ketiga dilakukan dengan menggunakan analisi varians factorial $2 \times 2$, perhitungan selengkapnya dapat dilihat pada lampiran. Rangkuman hasil perhitungannya pada tabel 2 sebagai berikut : 
JURNAL TEKNOLOGI INFORMASI \& KOMUNIKASI dalam PENDIDIKAN, Vol. 5 No. 1 Juni 2018, p-ISSN; 2355-4983, e-ISSN: 2407-7488

Tabel 2. Tabel Anava $2 \times 2$

\begin{tabular}{|c|c|c|c|c|}
\hline \multirow{2}{*}{ Minat Belajar } & \multirow[b]{2}{*}{ Statistik } & \multicolumn{2}{|c|}{ Model Pembelajaran } & \multirow[b]{2}{*}{ Total } \\
\hline & & Quantum Learning & Direct Teaching & \\
\hline \multirow{4}{*}{ Tinggi } & $\mathrm{N}$ & 19 & 20 & 39 \\
\hline & $\Sigma X$ & 544 & 480 & 1024 \\
\hline & $\Sigma X^{2}$ & 15960 & 11602 & 27562 \\
\hline & $\mathrm{M}$ & 28.63 & 24.00 & 52.63 \\
\hline \multirow{4}{*}{ Rendah } & $\mathrm{N}$ & 21 & 20 & 41 \\
\hline & $\Sigma X$ & 424 & 274 & 698 \\
\hline & $\Sigma \mathrm{X}^{2}$ & 15217 & 5612 & 20829 \\
\hline & $\mathrm{M}$ & 20.19 & 13.70 & 33.89 \\
\hline \multirow{4}{*}{ Total } & $\mathrm{N}$ & 40 & 40 & 80 \\
\hline & $\Sigma \mathrm{X}$ & 968 & 754 & 1722 \\
\hline & $\Sigma X^{2}$ & 31177 & 17214 & 48391 \\
\hline & $\mathrm{M}$ & 48.82 & 37.70 & 86.52 \\
\hline
\end{tabular}

Tabel 4.8. Ringkasan Perhitungan Anava Faktorial 2 x 2

\begin{tabular}{cccccc}
\hline Sumber & JK & Db & RJK & $F_{\text {h }}$ & $F_{\text {tab }}$ \\
Variasi & & & & & 3,26 \\
A & 572,45 & 1 & 572,45 & $\left.3,830^{*}\right)$ & 3,26 \\
B & 1703,54 & 1 & 1703,54 & $\left.11,397^{*}\right)$ & 3,26 \\
Inter AB & 68,102 & 1 & 68,102 & $\left.0,456^{\text {ns }}\right)$ & -- \\
dalam & 8980,86 & 36 & 149,47 & -- & \\
\hline Total & 11324,95 & 39 & -- & -- & \\
\hline
\end{tabular}

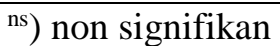

*) signifikan

$\left.\mathrm{F}_{\mathrm{A}}=3,830^{*}\right) \rightarrow$ signifikan, artinya : Terdapat perbedaan yang signifikan hasil belajar siswa antara yang diajar dengan model pembelajaran Quantum Learning dan Direct Teaching. Model pembelajaran berpengaruh terhadap peningkatan hasil belajar siswa.

Dengan demikian Ho ditolak dan $\mathrm{Ha}$ yang menyatakan terdapat perbedaan yang signifikan antara hasil belajar siswa yang diajar dengan model pembelajaran Quantum Learning dengan hasil belajar siswa yang diajar dengan Model pembelajaran Direct Teaching teruji kebenarannya. Dalam hal ini pembelajaran dengan menggunakan model pembelajaran Quantum Learning lebih baik dari pembelajaran dengan menggunakan Direct Teaching, dikarenakan nilai rata-rata hasil belajar siswa yang diajar Model pembelajaran Quantum Learning $(27,43)$ lebih tinggi dari nilai rata-rata hasil belajar siswa yang diajar dengan model pembelajaran Direct Teaching $(20,25)$.

$\left.\mathrm{F}_{\mathrm{B}}=11,397^{*}\right) \rightarrow$ signifikan, artinya $:$ Terdapat perbedaan yang signifikan hasil belajar siswa antara siswa yang memiliki minat belajar tinggi dan rendah. Minat belajar berpengaruh terhadap peningkatan hasil belajar. $\left.\mathrm{F}_{\mathrm{AB}}=0,456^{\mathrm{ns}}\right) \rightarrow$ non signifikan, artinya : Tidak terdapat interaksi antara model pembelajaran dengan minat belajar terhadap hasil belajar siswa.

\section{Hipotesis Pertama}

Pengujian hipotesis pertama untuk mengetahui pengaruh penggunaan model pembelajaran terhadap hasil belajar secara matematis dituliskan :

Ho: Tidak terdapat perbedaan hasil belajar antara siswa yang diajar dengan menggunakan model pembelajaran Quantum Learning dengan siswa yang diajar dengan model pembelajaran Direct Teaching.

Ha: Terdapat perbedaan hasil belajar antara siswa yang diajar dengan menggunakan model pembelajaran Quantum Learning dengan siswa yang diajar dengan model pembelajaran Direct Teaching. 
Berdasarkan tabel 4.8 terlihat bahwa nilai $F_{\text {hitung }}$ antar kolom lebih besar dari $F_{\text {tabel }}$ $\left(\mathrm{F}_{\text {hitung }}=3,830>\mathrm{F}_{\text {tabel }}=3,26\right)$ pada taraf signifuikan 5\%. Dengan demikian Ho ditolak dan Ha yang menyatakan terdapat perbedaan yang signifikan antara hasil belajar siswa yang diajar dengan model pembelajaran Quantum Learning dengan hasil belajar siswa yang diajar dengan model pembelajaran Direct Teaching teruji kebenarannya. Dalam hal ini pembelajaran dengan menggunakan model pembelajaran Quantum Learning lebih tinggi dari pembelajaran dengan menggunakan Direct teaching, dikarenakan nilai rata-rata hasil belajar siswa yang diajar model pembelajaran Quantum Learning $(18,7)$ lebih tinggi dari nilai rata-rata hasil belajar siswa yang diajar dengan Model pembelajaran Direct Teaching $(13,5)$.

\section{Hipotesis Kedua}

Pengujian hipotesis kedua untuk mengetahui pengaruh minat belajar terhadap hasil belajar secara matematis dituliskan :

Ho: Hasil belajar siswa pada mata Pelajaran Melakukan Prosedur Administrasi yang memiliki minat belajar tinggi sama dengan yang memiliki minat belajar rendah pada Jurusan Pendidikan Administrasi Perkantoran.

Ha: Hasil belajar siswa pada mata Pelajaran Melakukan Prosedur Administrasi yang memiliki minat belajar tinggi lebih tinggi dari yang memiliki minat belajar rendah pada Jurusan Pendidikan Administrasi Perkantoran.

Berdasarkan tabel 4.12 terlihat bahwa nilai $\mathrm{F}_{\text {hitung }}$ antar kolom lebih besar dari $\mathrm{F}_{\text {tabel }}$ $\left(\mathrm{F}_{\text {hitung }}=11,397>\mathrm{F}_{\text {tabel }}=3,26\right)$ pada taraf signifuikan $5 \%$. Dengan demikian Ho ditolak dan Ha yang menyatakan hasil belajar siswa pada mata Pelajaran Melakukan Prosedur Administrasi yang memiliki minat belajar tinggi lebih tinggi dari yang memiliki minat belajar rendah pada Jurusan Pendidikan Administrasi Perkantoran teruji kebenarannya.

\section{Hipotesis Ketiga}

Pengujian hipotesis ketiga untuk mengetahui pengaruh penggunaan Model pembelajaran dan minat belajar terhadap hasil belajar secara matematis dituliskan :

Ho : Tidak ada interaksi antara model pembelajaran dan minat belajar menggunakan komputer terhadap hasil belajar siswa pada mata Diklat Melakukan Prosedur Administrasi siswa
Jurusan Pendidikan Administrasi Perkantoran.

Ha : Ada interaksi antara model pembelajaran dan minat belajar menggunakan komputer terhadap hasil belajar siswa pada mata Diklat Melakukan Prosedur Administrasi siswa Jurusan Pendidikan Administrasi Perkantoran.

Berdasarkan tabel 4.15 diatas terlihat bahwa nilai $F_{\text {hitung }}$ antar kolom dan baris (interaksi) lebih kecil dari $\mathrm{F}_{\text {tabel }}\left(\mathrm{F}_{\text {hitung }}=0,456<\right.$ $\left.\mathrm{F}_{\text {tabel }}=3,26\right)$ pada taraf signifuikan 5\%. Dengan demikian Ho ditolak dan Ha yang menyatakan tidak terdapat interaksi antara penggunaan model pembelajaran dengan minat belajar dalam mempengaruhi hasil belajar tidak teruji kebenarannya.

\section{PEMBAHASAN}

Perbedaan Hasil Belajar Siswa yang diberi Pembelajaran Model pembelajaran Quantum Learning dan Pembelajaran Model pembelajaran Direct Teaching.

Model pembelajaran Quantum Learning merupakan model yang digunakan sebagai model dalam proses pembelajaran. Penggunaan model pembelajaran Quantum Learning dapat memberikan pengalaman yang nyata bagi siswa. Pengalaman nyata yang dimaksud dalam hal ini adalah interaksi langsung dari siswa dengan apa yang dipelajarinya itu sendiri. Model dalam proses pembelajaran merupakan alat yang paling efektif untuk mengikutsertakan berbagai indera dalam belajar. Ini disebabkan model pembelajaran Quantum Learning mempunyai penyampaian yang aktif, kreatif, efektif dan menyenangkan. Pengalaman nyata melibatkan orang yang belajar secara keseluruhan, baik fisik maupun indera dan inteleknya.

Dalam hal demikian belajar itu memberi rangsangan bagi keinginan untuk lebih banyak mengetahui. Belajar dari buku adalah salah satu metoda. Kita dapat belajar dari buku dengan baik kalau pelajaran yang terdapat didalamnya dihubungkan kepada sesuatu yang nyata dalam lingkungan yang sesungguhnya. Semua pelajaran demikian lebih mudah dimengerti dan lebih baik tinggal dalam ingatan jika dipelajari melalui hubungannya dengan benda sebenarnya.

Pembelajaran dengan menggunakan model pembelajaran Quantum Learning merupakan proses pembelajaran dimana siswa 
diajarkan dengan mengaitkan materi pelajaran dengan lingkungan dari materi pelajaran yang sedang dibahas. Siswa diperkenalkan langusng dengan benda asli dari materi pelajaran tersebut. Setiap bagian dari benada diperkenalkan langsung, sehingga siswa dapat lebih mengerti. Dalam proses pembelajaran ini, guru menerangkan materi pelajaraan dengan bantuan menggunakan alat peraga. Sebagai contoh, untuk menerangkan materi suratmenyurat, guru menerangkan materi dan memperkenalkan surat dan cara menuliskan surat menggunakan peralatan komputer serta menjelaskan setiap bagian-bagiannya.

Dalam penelitian ini, berdasarkan pengujian hipotesis pertama diperoleh penerapan pembelajaran dengan menggunakan model memberi pengaruh yang berbeda secara signifikan terhadap hasil belajar dimana $F_{\text {hitung }}$ $>\mathrm{F}_{\text {tabel }}$ sehingga untuk hipotesis penelitian yang pertama Ho diterima dan $\mathrm{Ha}$ ditolak. Berdasarkan hasil penelitian pembelajaran dengan menggunakan model direct teaching kurang efektif untuk memudahkan siswa dalam belajar, karena dalam pembelajaran ini indera siswa kurang dilibatkan secara keseluruhan sehingga mempengaruhi dalam proses daya tangkap siswa terhadap materi pelajaran. Sehingga dengan demikian pengetahuan yang mereka diperoleh tidak sebanyak yang didperoleh siswa yang diajarkan dengan menggunakan Model pembelajaran Quantum Learning.

Jadi, dari penelitian ini jelas bahwa pembelajaran dengan menggunakan model pembelajaran Quantum Learning akan memberi pengaruh yang lebih baik terhadap hasil belajar dibandingkan dengan pembelajaran menggunakan Model pembelajaran Direct Teaching.

\section{Perbedaan Hasil Belajar dari Siswa yang Memiliki Minat belajar tinggi dan Siswa yang Memiliki Minat belajar rendah.}

Tingkat minat belajar memberikan rasa lebih suka dan rasa ketertarikan terhadap bidang studi . Dalam hubungannya dengan belajar, seorang siswa akan lebih tertarik untuk belajar atas dasar keinginannya akan sesuatu hal yang hendak dipelajari. Seorang yang memiliki minat belajar yang tinggi ia akan memilki keinginan yang kuat untuk menguasai materi dan memecahkan masalah yang akan diajarkan itu sehingga akhirnya dapat mencapai hasil yang maksimal. Tetapi sebaliknyua seorang yang memiliki minat belajar yang rendah cenderung menyerah terhadap masalah yang dihadapi dan kurang memiliki keinginan yang kuat untuk mengasai materi yang akan diajarkan itu sehingga akhirnya kurang dapat mencapai hasil yang maksimal.

Dalam penelitian ini, berdasarkan pengujian hipotesis kedua terbukti bahwa tinggi rendah tingkat minat belajar memberi pengaruh yang berbeda secara signifikan terhadap hasil belajar dimana $F_{\text {hitung }}>F_{\text {tabel }}$ sehingga untuk hipotesis penelitian yang pertama Ha diterima dan Ho ditolak.

\section{Interaksi Antara Model pembelajaran dan Minat belajar Dalam Mempengaruhi hasil Belajar}

Penelitian ini menyimpulkan bahwa tidak ada interaksi antara pembelajaran dengan menggunakan model pembelajaran dengan minat belajar siswa terhadap hasil belajar. Tampak pada grafik di atas bahwa penelitian ini menunjukkan penerapan pembelajaran dengan model pembelajaran Quantum Learning dan penerapan dengan direct teaching member pengaruh yang berbeda secara signifikan terhadap hasil belajar siswa terlepas dari minat belajar siswa. Sebaliknya minat belajar tinggi dan minat belajar rendah siswa memberi pengaruh yang berbeda terhadap hasil belajar terlepas dari Model pembelajaran yang digunakan. Sehingga hipotesis yang diajukan ditolak (Ha ditolak). Untuk itu perlu dilakukan mengkaji ulang kembali kajian teori pada penelitian, karena penelitian dan teknik analisis data telah dilakukan sesuai dengan desain rancanagan penelitian.

Banyak faktor yang mempengaruhi hasil belajar siswa yaitu dari factor internal, factor eksternal, dan factor pendekatan balajar, salah satunya misalnya adalah factor kelengkapan fasilitas belajar pribadi dari siswa, atau persepsi yang berbeda dari setiap siswa dalam memandang mata pelajaran tersebut. Faktor-faktor tersebut juga dalam banyak hal sering saling berkaitan dan mempengaruhi satu sama lain, namun tidak menutup kemungkinan juga apabila hal tersebut tidak saling mempenagruhi. Hal tersebut mungkin dapat disebabkan oleh karena siswa tersebut memiliki intelegensi tinggi (faktor internal) sehingga lebih cenderung untuk memilih pendekatan pembelajaran yang hanya mengutamakan hasil belajar saja. Banyak faktor pendekatan lainnya yang turut mempengaruhi hasil belajar siswa. 
Untuk itu alas an mengapa tidak ada interaksi antara pembelajaran dengan menggunakan Model dengan minat belajar siswa terhadap hasil belajar, kemungkinan karena adanya pengaruh minat belajar siswa dengan adanya model pembelajaran dapat menyamai kondisi lain dalam diri subjek yang belum dapat diamati (intervening variable). Kalau benar demikian, mungkin dapat diterima bahwa minat belajar siswa dan pembelajaran dengan menggunakan Model memberi pengaruh yang berbeda terhadap hasil belajar.

Oleh karena itu penelitian ini merupakan untuk mendriskripsikan factor apa yang menyebabkan masalah belajar, khususnya dalam model pembelajaran yang tepat untuk digunakan dan menguasai factor yang menghambat proses belajar siswa tersebut.

\section{PENUTUP}

Berdasarkan hasil penilitian yang telah di uraikan pada bab sebelumnya, maka dapat di tarik beberapa kesimpulan sebagai berikut :

1. Terdapat perbedaan hasil belajar melakukan prosedur administrasi antara kelompok siswa yang diajar dengan model pembelajaran quantum learning dengan siswa yang diajar dengan model pembelajaran direct teaching. Kelompok siswa yang diajarkan dengan model pembelajaran quantum learning memperoleh hasil melakukan prosedur administrasi lebih tinggi dari pada kelompok siswa yang diajar dengan strategit direct instruction dimana (f hitung $=3,830>\mathrm{F}$ tabel=3,26).

2. Terdapat perbedaan hasil belajar melakukan prosedur administrasi antara kelompok siswa yang memiliki minat belajar tinggi dengan kelompok siswa yang memiliki minat belajar rendah. Siswa yang memiliki minat belajar tinggi memperoleh hasil belajar tinggi dari pada kelompok siswa yang memiliki minat belajar rendah dimana $(\mathrm{F}$ hitung $=11,397>\mathrm{F}$ tabe $1=3,26)$

3. Tidak ada interaksi antara penerapan pembelajaran dengan model pembelajaran dengan model pembelajaran quantum learning dan model pembelajaran direct instruction dengan tinggi rendahnya minat belajar terhadap hasil belajar melakukau prosedur administrasi siswa kelas X SMK PAB 12 Saentis Percut Sei Tuan dimana (F hitung $=0,456<\mathrm{F}$ tabel $=3,26$ ).

\section{DAFTAR PUSTAKA}

Arikunto S., 2010. Prosedur penelitian, suatu pendekatan praktek. Jakarta : Rineka Cipta

Dirullah Dikdik.Munir.dkk. 2013 . Penerapan model pembelajaran Quantum learning untuk Meningkatkan hasil belajar siswa mata pelajaran teknologi informasi dan komunikasi. Studi quasi eksperimental terhadap siswa kelas VII SMP negeri 4 Cimahi. Jurnal ilmiah kependidikan Vol 4. No 1.8 maret 2015

De Porter Bobbi dan Mike Hernacki. 2013. Quantum learning membacakan belajar nyaman dan menyenangkan. Bandung : Kaifa

De Porter Bobbi, Reardon,Dkk. 2001. Mempraktikkan quantum learning di ruang-ruang kelas.Terjemahan Ary Nilandari. Quantum Teaching: Orkestrating Student Success. 1999. Bandung: Kaifa.

Depdiknas. 2006. Bunga Rampai Keberhasilan Guru dalam Pembelajaran (SMA, SMK, dan SLB). Jakarta: Depdiknas.

Dimyati dan Mudjiono. 2009. Belajar dan Pembelajaran. Jakarta: PT Rineka Cipta.

Hamalik, Oemar. 2006. Proses Belajar Mengajar. Jakarta: PT Bumi Aksara

Agung. 2008.Ensiklopedia Teknologi informasi dan komunikasi .Semarang : PT.Bangawan Ilmu

Kusmulyadi.dkk 2009.Teknologi Informasi Dan komunikasi. bandung: CV Thursina.

Rachman Arif.2009. Menulis Surat. Bandung : Adhi aksara abadi indonesia

Rasyid Harun,Mansyur. 2007. Penilaian Hasil belajar. Bandung : CV Wacana prima

Sutrisno. Tjarijasih Liyah. 2006. Melakukan Prosedur Administrasi.Yudhistira

Susiliana, Rudi dan Riyana, Cepi. 2007. Media pembelajaran. Hakekat Pengembangan pemanfaatan dan penilaian. Bandung : CV Wacana Prima

Sumiati dan Edi . 2007. Metode pembelajaran . Bandung : CV Wacana Prima

Sofyan .Tis 2008 surat online tersedia :http;elib.unikom.ac.id

Shortcut Beserta penjelasannya .www.ilmu computer.com

Silberman Melr.2009. Active learning strategi pembelajaran Aktif . Yogyakarta : Insan Madani 
JURNAL TEKNOLOGI INFORMASI \& KOMUNIKASI dalam PENDIDIKAN, Vol. 5 No. 1 Juni 2018, p-ISSN; 2355-4983, e-ISSN: 2407-7488

Sudjana, Nana. 2010. Penilaian Hasil Proses Belajar Mengajar. (Cet. XV). Bandung: PT. Ramaja Rosdakarya.

Torar Lexi. 2010. Media Teknologi informasi dan komunikasi. Semarang : PT.Multi kreasi satu delapan

Uno, Hamzah B., Abdul Karim Rauf, dan Najamuddin Petta Solong. 2008. Pengantar Teori Belajar dan Pembelajaran. (Cet. II). Gorontalo: Nurul Jannah.

Usman, Moh Uzer dan Lilis Setiawati. 2001. Upaya Optimalisasi Kegiatan Belajar Mengajar. Bandung: Remaja Rosdakarya.

Wahidmurni, Alifin Mustikawan, dan Ali Ridho. 2010. Evaluasi Pembelajaran: Kompetensi dan Praktik. Yogyakarta: Nuha Letera. 